\title{
The Relationship Between Gesture and Speech in Preschool Children with Expressive Specific Language Impairment and Typically Developing Children
}

\author{
Sujin Choi ${ }^{1}$, Sang-Im Jung ${ }^{2}$, Young Tae Kim ${ }^{3}$ \\ Ph. D. Student, Department of Communication Disorders, Ewha Womans University, Seoul, Korea ${ }^{2}$ \\ Professor, Department of Communication Disorders, Ewha Womans University, Seoul, Korea ${ }^{3}$ \\ 취학 전 표현언어부진 아동과 일반 아동이 사용하는 \\ 제스처와 발화의 관계 특성 비교 \\ 최수진 ${ }^{1}$, 정상임 ${ }^{2}$, 김영태 ${ }^{3}$ \\ 이화여자대학교 언어병리학과 석사과정생, 이화여자대학교 언어병리학과 박사과정생 ${ }^{2}$, \\ 우송대학교 언어치료·청각재활학과 초빙교수 ${ }^{2}$, 이화여자대학교 언어병리학과 교수 ${ }^{3}$
}

Master's Student, Department of Communication Disorders, Ewha Womans University, Seoul, Korea ${ }^{1}$ Invited Professor, Department of Speech Language Therapy and Aural Rehabilitation, Woosong University, Daejeon, Korea ${ }^{2}$

\begin{abstract}
Objectives: The purpose of this study was to investigate the relationship between gesture and speech in the preschool children with expressive language impairment (E-SLI).

Methods: Thirty-six preschool children-12 E-SLI, 12 typically developing children matched for chronological age (CA-TD), and 12 typically developing children matched for language age (LA-TD)completed a picture naming task and a description task. Three-way mixed analysis of variance was used to analyze the modality of expression, the types of gestures, and the semantic relationship between gestures and co-occurring speech.

Results: The frequency of 'speech + gesture' in children with E-SLI was significantly higher than in CA-TD children. In addition, the frequency of 'only speech' and 'speech + gesture' in children with E-SLI was similar to that in LA-TD children. In terms of the gesture types, children with E-SLI used significantly more deictic gestures than CA-TD children did. Further, the frequency of representational gestures in children with E-SLI was similar to that of LA-TD children.

Conclusion: In educational and clinical settings, it is important to acknowledge that the gestures accompanying with limited verbal expression in children with E-SLI deliver additional semantic information. Therefore, it is essential for educators and clinicians to carefully examine the use of gestures when treating children with E-SLI .
\end{abstract}

Keywords: speech \& gesture, expressive specific language impairment, nonverbal communication

\section{Introduction}

우리는 다양한 방법을 통해 자신의 의사를 표현하고 타인과 소통한다. 가장 대표적인 의사소통 수단인 말과 글 이외에도,

Corresponding Author: Young Tae Kim, Professor, Department of Communication Disorders, Ewha Womans University, 52 Ewhayeodae-gil, Seodaemun-gu, Seoul 03760, Korea

E-mail: youngtae@ewha.ac.kr
얼굴의 표정이나 몸을 사용한 제스처, 사진이나 그림 등의 비 언어적인 수단을 통해서도 메시지를 주고받는다. 이러한 다양 한 의사소통 수단 중 제스처는 매우 이른 시기부터 나타나는 데, 아직 명확한 발화를 보이지 않는 영유아도 다양한 제스처

CThe Korean Association of Child Studies

This is an Open Access article distributed under the terms of the Creative Commons Attribution Non-Commercial License (http:// creativecommons.org/licenses/by-nc/4.0) which permits unrestricted noncommercial use, distribution, and reproduction in any medium, provided the original work is properly cited. 
를 사용하여 다양한 의사를 표현할 수 있다. 또한 제스처 발달 은 이후 구어 표현 기술을 보완하고, 구어 발달 능력을 예측할 수 있게 하는 역할을 한다(Capone \& McGregor, 2004)는 면에 서 의사소통발달 평가에 중요한 요소이다.

아동들은 첫 단어를 산출한 이후에도 계속해서 발화와 함 께 제스처를 조합하여 사용해나가며, 어휘력이 발달해나감에 따라 제스처와 발화의 관계가 변하기도 한다(Stefanini, Bello, Caselli, Iverson, \& Volterra, 2009). 아동의 언어발달이 급격하 게 진행되는 단어 폭발기에는 단어를 학습하는 상황에서 제스 처와 발화 간 불일치 조합이 자주 나타난다(Gershkoff-Stowe \& Smith, 1997). 발달시기에 따라 살펴보면 18-20개월 경 구어 표 현이 증가하면서 제스처와 발화의 조합이 나타나며, 20 개월 이후부터는 제스처로만 의사소통 의도를 전달하기보다 '발화' 또는 '발화 + 제스처'의 형태로 의사소통 의도를 표현한다. 이 후 2-5세에는 구어와 제스처가 통합되고 도상적 제스처가 활 발해지는 특성을 보인다(Capone \& McGregor, 2004; Hong \& Kim, 2001).

이렇듯 여러 학자들은 아동이 산출하는 발화뿐만 아니라 제스처에도 관심을 두며 발화와 제스처가 어떠한 관계를 가 지고 있는지에 대하여 분석하였는데, 선행연구들에서 사용 된 제스처 유형과 발화 + 제스처 조합의 의미론적 관계에 대 한 분석 기준은 학자들마다 조금씩 차이가 있다. 먼저 제스 처 유형 분류 방식을 살펴보면, 몇몇 학자들은 크게 지시적 제스처(dietic gesture), 표상적 제스처(representational gesture), 기타 제스처로 나누었다(Bello, Capirci, \& Volterra, 2004; Butcher \& Goldin-Meadow, 2000; Stefanini, Caselli, \& Volterra, 2007). 그들은 지시적 제스처를 보여주기(showing), 건네주기 (giving), 가리키기(pointing)로 나누었고, 표상적 제스처는 행 위 제스처와 크기-형태 제스처로 분류하였다. 기타 제스처 는 관습적(conventional) 제스처, 비트(beat) 제스처, 버터워스 (Butterworth) 제스처로 나누었다. Őzçalişkan과 Goldin-Meadow (2005)는 지시적, 관습적, 표상적, 비트 제스처로 크게 네 가지 로 분류하였다. 또 다른 학자들은 지시적 제스처와 표상적 제 스처의 큰 두 분류 체계를 적용한 후, 다시 지시적 제스처를 지 적하기와 도구적 제스처로, 표상적 제스처를 관습적 제스처와 도상적 제스처로 분류하였다(An, Bang, \& Lee, 2010; Capirci, Iverson, Pizzuto, \& Volterra, 1996; H. Park, 2013).

아동이 산출한 발화 + 제스처 양상의 의미적 관계에 대 한 분석 연구들의 경우에도 학자들마다 조금씩 다른 분석 체계를 사용한 것을 볼 수 있다. Lavelli, Barachetti와 Florit (2015)는 발화 + 제스처 양상을 '강화(reinforcing)', '명확성 (disambiguating)', '추가(adding)'의 총 세 가지의 유형으로 나누 었다. Lavelli와 Majorano (2016)는 제스처와 발화의 정/오반응 형태에 따라 크게 두 가지 유형 강화와 추가로 나누었고, 이를 다시 두 가지 하위유형으로 나누어 총 네 가지로 분류하여 분 석하였다.

최근에는 제스처 유형과 발화와 제스처 간 관계에 대한 분 석이 활발해지면서 의사소통의 다중방식적 특성이 강조되고, 제스처의 역할이 더욱 주목을 받고 있다. 이에 따라 제스처가 조기언어중재의 유용한 수단으로 간주되고 있다. 특히 조기중 재를 받지 못하면 학령기에 들어 학습장애의 고위험군이 될 가능성이 높은 것으로 알려져 있는 단순언어장애 아동들은 일 반아동들에 비해 그림을 인식하고 이름을 명명하는 속도가 더 느린 특성을 보인다(Lahey \& Edwards, 1996). 목표단어의 이해 와 표현과 관련하여 단순언어장애 아동들은 생활연령과 언어 능력이 일치한 일반아동들보다 음운적 오류를 더 많이 보이 는 것으로 보고되었다(Majorano \& Lavelli, 2014). 더불어 단순 언어장애 아동들이 일반아동에 비해 낱말 찾기 반응의 정확성 도 떨어진다는 연구결과도 보고된 바 있다(Lahey \& Edwards, 1999). 이러한 단순언어장애 아동들은 낱말 찾기의 어려움이 생길 때 비언어적인 음성 형태를 사용하거나 판토마임이나 제 스처로 표현하기, 정확한 낱말 대신 에둘러 표현하기 등의 특 성을 보인다(Johnson \& Myklebust, 1967).

단순언어장애 아동의 제스처와 발화 간 관계에 중점을 두 어 단순언어장애 아동이 일반아동 보다 제한된 언어능력을 보 완하기 위해 제스처를 사용하는지를 분석한 연구들을 살펴보 면, 어휘학습에 관한 연구 결과와 일관되게 단순언어장애 아 동들은 어휘 발달을 위해 제스처를 하나의 단서로 사용했음 을 알 수 있다(Weismer \& Hesketh, 1993; Majorano \& Lavelli, 2014).

내러티브, 만화 다시 말하기, 책 읽기 등의 다양한 과제를 통해 단순언어장애 아동과 일반 아동 간 발화 + 제스처 조합 의 의미적 관계를 분석한 연구 결과들을 살펴보면, 연구에 따 라 과제나 분석법들이 다르고 결과 또한 상이하다. Lavelli 등 (2015)과 Lavelli와 Majorano (2016)는 표현언어부진아동과 언 어연령을 일치시킨 일반아동 간 제스처 비율이 하다고 보고한 반면, Blake, Myszczyszyn와 Bebiroglu (2008)는 단순언어장애 아 동과 언어연령을 일치시킨 일반아동 간 제스처 비율에 유의한 차이가 있다고 보고했다. Lavelli 등(2015)과 Lavelli와 Majorano (2016)는 일반아동보다 표현언어부진 아동들의 제스처 비율 이 유의하게 높은 것으로 보고하였으며, Blake 등(2008)은 발 화 + 제스처(bimodal)의 비율에서 그룹 간 유의미한 차이는 발 
견되지 않았으나 단순언어장애 아동들은 일반아동들보다 단 어를 더 자주 대체하여 제스처로 의미 정보를 전달한다고 하 였다. Lavelli 등(2015)과 Lavelli와 Majorano (2016)에서는 단순 언어장애 아동에게서 발화 + 제스처(bimodal)의 비율이 유의 하게 높았다고 보고하였으나, Mainela-Arnold, Alibali, Hostetter 와 Evans (2014)의 연구에서는 차이가 없는 것으로 나타났다.

이상의 선행연구들을 종합하여 보면, Lavelli 등(2015)과 Lavelli와 Majorano (2016)의 연구를 제외하고는 학령기 아동 과 언어연령을 일치시킨 일반아동을 대상으로 한 연구는 없으 며, 그 외의 연구들은 수용·표현 영역 모두에 지연이 있는 단순 언어장애 아동들을 대상으로 한 연구들이 대부분인 것으로 보 인다. 다시 말해 취학 전 표현언어에만 지연이 있는 표현언어 부진 아동과 언어연령을 일치시킨 일반아동과의 비교 연구는 아직 부족함을 알 수 있다. 이와 함께 선행연구들은 과제, 대상 자, 분석법에 서로 차이가 커 각 연구결과들의 비교가 어렵다 는 한계가 있다. 또한 현재까지 국내 언어병리학 분야에서의 제스처 연구는 극소수에 불과하고, 대부분 요구하기나 지적하 기와 같은 초기 의사소통 기능을 가르치기 위한 수단으로만 고찰되었을 뿐(Kang, 2009; M. Kim \& Son, 2006), 아동들이 어 떠한 제스처와 발화를 조합하여 사용하고, 그 제스처와 발화 는 서로 어떠한 의미적 관계를 가지고 있는지에 대한 분석은 이루어지지 않았다.

지금까지 여러 학자들은 취학 전 표현언어부진 아동들이 취학 후 학업 수행에 어려움을 겪을 가능성이 높으므로, 학령 전기에 표현언어발달 지연이 있는 아동에 대해 지속적인 관심 을 갖고 적절한 중재를 하는 것은 매우 중요하다고 지적하였 다. 때문에 우리는 표현언어부진 아동의 제스처 사용이 발화 와 어떠한 관계 및 특성을 가지고 있는지 파악하여 이를 교육 현장 및 임상에서 적절하게 중재하는 것이 필요하겠다.

따라서 본 연구에서는 취학 전 표현 언어에서만 지연 을 보이는 표현언어부진 아동(Expressive Specific Language Impairment [E-SLI]), 그들과 생활연령을 일치시킨 일반아동 (Typically Developing Children matched for Chronological Age [CA-TD]), 그리고 언어연령을 일치시킨 일반아동(Typically Developing Children matched for Language Age [LA-TD]) 세 집 단을 대상으로 이름대기 과제와 아동의 언어적인 부담을 높인 설명하기 과제를 실시하여 두 과제에서 산출되는 발화와 제스 처를 아래와 같이 크게 세 가지로 나누어 비교 분석해 보고자 한다. 첫 번째로 아동이 산출한 발화와 제스처의 양상을 발화, 발화 + 제스처, 제스처로 나누고, 두 번째로는 아동이 산출한 제스처 유형을 '지시적 제스처', ‘표상적 제스처', '기타 제스처'
로 분류하고자 한다. 마지막으로 아동이 산출한 발화 + 제스 처 양상 중 의미적 정보를 포함하고 있는 표상적 제스처와 발 화가 어떠한 의미적 관계를 가지고 있는지 '정확한 발화 + 정 확한 제스처', '부정확한 발화 + 정확한 제스처', '정확한 발화 + 부정확한 제스처', ‘부정확한 발화 + 부정확한 제스처'로 나누 어 분석해 보고자 한다. 이에 대한 구체적인 연구문제는 다음 과 같다.

\section{연구문제 1}

취학 전 아동의 발화 및 제스처 사용 빈도는 집단(E-SLI, CA-TD, LA-TD), 과제(이름대기, 설명하기) 및 발화-제스처 산출양상(발 화, 발화 + 제스처, 제스처)에 따라 유의한 차이가 있는가?

\section{연구문제 2}

취학 전 아동의 제스처 사용은 집단, 과제 및 제스처 유형(지 시적 제스처, 표상적 제스처, 기타 제스처)에 따라 유의한 차 이가 있는가?

\section{연구문제 3}

취학 전 아동의 발화와 함께 나타나는 표상적 제스처 사용 빈 도는 집단, 과제 및 발화-제스처 의미적 관계 유형에 따라 유 의한 차이가 있는가?

\section{Methods}

\section{연구대상}

본 연구는 생활연령 3-5세인 표현언어부진 아동과 표현언어 부진 아동과 생활연령을 일치시킨 일반아동, 표현언어부진 아 동과 언어연령을 일치시킨 일반아동 각각 12 명씩 총 36 명을 대상자로 선정하였다. 연구자는 모든 아동의 부모에게 검사 내용에 대해 설명하였고, 연구 참여에 동의한 경우 동의서를 작성하도록 하였다.

\section{표현언어부진 아동}

Leonard (2014)의 단순언어장애 아동의 선별기준을 참고하여 선정한 표현언어부진 아동의 선별기준은 다음과 같다. (1) 생 활연령이 만 4-5세 사이에 속하고, (2) 한국 카우프만-아동지 능검사(K-ABC II; Mun, 2014)의 비언어성 지능지수가 85 이 
Table 1

Characteristics of Participants

\begin{tabular}{lccc}
\hline & E-SLI $(N=12)$ & CA-TD $(N=12)$ & LA-TD $(N=12)$ \\
\cline { 2 - 4 } & $M(S D)$ & $M(S D)$ & $M(S D)$ \\
\hline CA & $57.92(4.96)$ & $58.75(4.65)$ & $45.08(5.11)$ \\
\hline PIQ & $100.17(12.20)$ & $103.58(11.79)$ & $403.17(14.84)$ \\
\hline E-LA & $46.50(2.71)$ & $63.17(4.73)$ & $49.67(5.38)$ \\
\hline
\end{tabular}

Note. $\mathrm{CA}=$ chronological age; PIQ $=$ performance intelligence quotient; E-LA $=$ expressive language age; E-SLI $=$ children with expressive specific language impairment; CA-TD = typically developing children matched for chronological age; LA-TD = typically developing children matched for language age.

상이며, (3) 취학전 아동의 수용언어 및 표현언어 발달척도 (PRES; Y. Kim, Sung, \& Lee, 2003) 결과 수용언어는 또래 규준 에서 정상범위에 해당하고 표현 언어가 또래 규준에서 $10 \%$ ile 미만에 해당하며, (4) 부모 및 교사에 의해 행동, 기타 정서, 감 각(시각 및 청각), 신경학적인 결함, 구강구조 및 기능의 이상 의 이력이 없다고 보고 된 아동으로 선정하였다.

\section{표현언어부진 아동과 언어연령을 일치시킨 일반아동}

표현언어부진 아동과 언어연령을 일치시킨 일반아동의 선별 기준은 다음과 같다. (1) 생활연령이 만 3-4세 사이에 속하고, (2) 한국 카우프만-아동지능검사(K-ABC II; Mun, 2014)의 비 언어성 지능지수가 85 이상이며, (3) 취학전 아동의 수용언어 및 표현언어 발달척도(PRES; Y. Kim et al., 2003)에서 검사 결 과 표현언어부진 아동의 표현언어연령과 \pm 3 개월 연령대에 속 하며, 수용언어는 또래 규준에서 정상범위에 해당하고 (4) 부 모 및 교사에 의해 행동, 기타 정서, 감각(시각 및 청각), 신경 학적인 결함, 구강구조 및 기능의 이상의 이력이 없다고 보고 된 아동으로 선정하였다.

\section{표현언어부진 아동과 생활연령을 일치시킨 일반아동}

표현언어부진 아동과 생활연령을 일치시킨 일반아동의 선별 기준은 다음과 같다. (1) 생활연령이 만 4-5세 사이에 속하고, (2) 한국 카우프만-아동지능검사(K-ABC II ; Mun, 2014)의 비 언어성 지능지수가 85 이상이며, (3) 취학전 아동의 수용언어 및 표현언어 발달척도(PRES; Y. Kim et al., 2003) 결과 수용·표 현 언어가 또래 규준에서 정상범위에 해당하고, (4) 부모 및 교 사에 의해 행동, 기타 정서, 감각(시각 및 청각), 신경학적인 결 함, 구강구조 및 기능의 이상의 이력이 없다고 보고 된 아동으 로 선정하였다.
표현언어부진 집단의 평균 생활연령은 57.92개월이었으며 생활연령일치 집단의 평균 생활연령은 58.75 개월이었다. 표 현언어부진 집단과 생활연령일치 집단 간 생활연령에 대해 $t$ 검증을 실시해본 결과, 표현언어부진 집단과 생활연령일치 집단 간 유의한 차이가 없는 것으로 나타났다 $\left(t_{22}=-.425, p\right.$ > .05). 또한 표현언어부진 집단의 언어연령은 46.50 개월이었으 며, 언어연령일치 집단의 언어연령은 49.67 개월이었다. 두 집 단간 표현언어연령에 대해 $t$-검증을 실시해본 결과, 표현언어 부진 집단과 언어연령일치 집단 간 유의한 차이가 없는 것으 로 나타났다 $\left(t_{22}=-1.820, p>.05\right)$. 집단 간 생활연령과 동작성 지능, 표현언어연령은 Table 1에 제시하였다.

\section{연구도구}

$$
\text { 기초 검사 도구 }
$$

취학 전아동의 수용 언어 및 표현언어 발달 척도 취학 전 아동 의 수용언어 및 표현언어 발달척도(PRES; Y. Kim et al., 2003) 는 2세부터 6 세 사이의 아동들의 전반적인 언어발달 정도를 평가하기 위한 목적으로 고안된 표준화 검사도구이다. 본 검 사는 수용언어와 표현언어 영역으로 구성되어있다. 본 연구에 서는 대상 아동의 전반적인 수용 및 표현언어의 발달 정도를 알아보고자 실시하였다.

한국 카우프만-아동지능검사 한국 카우프만-아동지능검사 (K-ABC II ; Mun, 2014)는 만 3세에서 18세 사이의 아동 및 청 소년의 지능을 측정할 수 있도록 고안된 표준화 지능 검사이 다. 본 연구에서는 대상 아동의 비언어성 지능이 정상 범주에 해당하는지를 살펴보기 위해 동작성 지능검사를 실시하였다. 만 3-4세의 경우 관계유추, 얼굴기억, 삼각형, 손동작 하위 검 사를 실시하였고, 만 5세의 경우 관계유추, 얼굴기억, 삼각형, 
형태추리, 손동작 하위 검사를 실시하였다.

\section{본 연구 과제}

이름대기 과제 한국어 발달 과정에 적절한 어휘를 선정하기 위해 K M-B CDI (Pae \& Kwak, 2011)를 참고하여, 36개월 이 내의 아동들이 이해하고 표현할 수 있는 명사, 동사, 형용사 어 휘들을 선택하였다. 또한 Lavelli와 Majorano (2016)에서 사용 한 이름대기 검사 PiNG와 H. J. Park과 Kim (2018)에서 사용한 도상적 제스처 어휘 이해 및 표현 목록을 참고하여 어휘목록 을 최종 선정하였다. 품사 별 어휘 수는 명사 10 개, 동사 10 개, 형용사 10 개 총 30 개로 Table 2 와 같다.

설명하기 과제 선행연구들에서는 사용된 이름대기 과제는 검사 방법이 간단하다는 장점이 있으나, 비교적 인지 및 언어 적 부담이 적은 과제이므로 아동의 충분한 발화와 제스처를 유도하는 것에는 한계가 있었다. 따라서 본 연구는 이러한 점 을 보완하여, 이름대기 과제보다 인지 및 언어적 능력이 더 요 구되는 설명하기 과제를 추가하였고, 이를 통해 좀 더 자연스 러운 대화 상황에서 아동의 발화와 제스처를 충분히 수집하고 자 하였다.

설명하기 과제에서 사용된 어휘는 이름대기 과제와의 차이 를 최대한 줄이기 위해 이름대기 과제에서 사용한 어휘와 특 성이 유사하도록 선정하였고, 이름대기 과제의 어휘 수와 동 일하게 30 개의 문항으로 구성하였다. 두 과제의 명사 어휘는 하나의 범주로 일치시켰고, 동사 어휘는 목적어를 필요로 하 는 타동사로 선정하여 선행하는 목적어를 일치시켰으며, 형용 사 어휘는 서로 의미가 반대되는 어휘로 선정하여 두 과제 어 휘 특성이 유사하도록 고려하였다. 본 과제에서 선정한 어휘 는 K M-B CDI (Pae \& Kwak, 2011)에 사용된 36개월 이내의 아 동들이 이해하고 표현하는 명사, 동사, 형용사 어휘목록을 참 고하였다. 품사별 어휘 수는 명사 10 개, 동사 10 개, 형용사 10 개 총 30 개의 문항으로 Table 2에 제시하였다.

본 연구에서 사용한 이름대기 과제 어휘와 설명하기 과제 어휘는 전문가 5 명 1 급 언어재활사 자격증을 소지한 언어병 리학 박사 과정)에게 내용타당도를 평가받았다. 내용타당도 를 평가하기 위한 설문지 내용으로는 (1) 두 과제의 어휘들이 3-5세 아동이 이해하고 표현할 수 있는 어휘인지 (2) 두 과제의 어휘 특성은 서로 유사한지를 묻는 문항들로 구성하였으며 5 점 척도(전혀 그렇지 않다 [1], 그렇지 않다 [2], 보통이다 [3], 그런 편이다 [4], 매우 그렇다 [5])를 사용하였다. 그 결과, 이름
Table 2

Words Used in Naming \& Description Tasks

\begin{tabular}{|c|c|c|c|}
\hline & No. & Words in naming task & Words in description task \\
\hline \multirow{10}{*}{$\begin{array}{l}\text { Nouns } \\
(n=10)\end{array}$} & 1 & Tiger & Cat \\
\hline & 2 & Car & Fire truck \\
\hline & 3 & Glasses & Hat \\
\hline & 4 & Camera & Vacuum cleaner \\
\hline & 5 & Spoon & Fork \\
\hline & 6 & Umbrella & Rain boots \\
\hline & 7 & Cup & Bottle \\
\hline & 8 & Air plane & Helicopter \\
\hline & 9 & Tooth brush & Toothpaste \\
\hline & 10 & Gun & Sword \\
\hline \multirow{10}{*}{$\begin{array}{l}\text { Verbs } \\
(n=10)\end{array}$} & 1 & Eat & Spit \\
\hline & 2 & Beat & Push \\
\hline & 3 & Throw & Kick \\
\hline & 4 & Drive & Ride \\
\hline & 5 & Fold & Fly \\
\hline & 6 & Cut & Cook \\
\hline & 7 & Blow & Pop \\
\hline & 8 & Hang & Wear \\
\hline & 9 & Grab & Put \\
\hline & 10 & Turn off & Turn on \\
\hline \multirow{10}{*}{$\begin{array}{l}\text { Adjectives } \\
(n=10)\end{array}$} & 1 & Heavy & Light \\
\hline & 2 & Small & Big \\
\hline & 3 & Hot & Cold \\
\hline & 4 & Hungry & Full \\
\hline & 5 & Cold & Hot \\
\hline & 6 & Round & Sharp \\
\hline & 7 & Same & Different \\
\hline & 8 & Dirty & Clean \\
\hline & 9 & Dark & Bright \\
\hline & 10 & Long & Short \\
\hline
\end{tabular}

대기 과제와 설명하기 과제 어휘의 내용 타당도는 어휘의 난 이도 4.45점, 어휘의 균형 4.34점으로 평가되어 모두 타당한 것으로 나타났다.

\section{연구절차}

본 연구에 사용한 그림 자료는 아동의 제스처와 발화 산출을 용이하게 하기 위해 달력형 책자로 만들었고, 색칠된 그림 자 료를 사용하였다. 검사 실시 전 검사자는 아동과 친숙해지기 위해 5-10분 정도 놀이 및 대화를 실시하였다. 검사는 아동에 게 친숙한 공간인 가정에서 실시하였고, 과제에 집중할 수 있 
도록 조용한 공간에서 진행하였다. 또한 아동은 테이블 및 의 자에 착석하여 검사자와 마주 앉도록 하였다. 과제 수행 동안 아동의 전면부에 카메라를 설치하여 아동의 상체가 잘 보이도 록 캠코더를 삼각대에 고정하여 촬영하였다.

\section{이름대기 과제}

검사자는 아동과 마주보고 앉은 후 그림을 아동에게 보여주었 다. 아동이 검사자의 질문과 과제물에 친숙해지게 하기 위해 연습문항 2 개를 실시한 후 본 문항을 실시하였다. 명사의 경 우 “이게 뭐야?”라고 물어보았고, 동사의 경우 “친구가 뭐하 고 있어?”, 형용사의 경우 “이건 어때?”라고 질문하였다. 첫 번 째 시도에서 아동이 응답하지 않는 경우 10 초 동안 반응을 기 다려 주었고, 이후에도 반응이 없다면 두 번째까지 기회를 제 공해주었다.

\section{설명하기 과제}

검사자와 아동이 책상에 마주앉아 그림 책자를 세워 아동을 향하도록 하고, 검사자는 아동에게 제공한 목표어휘그림과 그 와 특성이 유사한 어휘그림이 포함된 두개의 그림을 검사자 의 시선방향으로 두고 검사자가 보고 있는 그림은 아동 눈에 도 보이도록 하였다. 아동에게 제공된 그림판은 1 개의 목표그 림으로만 이루어져 있으며, 검사 시작 전 아동이 과제를 충분 히 이해하도록 연습문항 6개(명사, 동사, 형용사 각 2개)를 실 시하였다. 스티커를 준비한 후 검사자는 아동에게 " $\bigcirc$ 아, 여기 그림이 있어. 이 그림은 $\bigcirc \bigcirc$ 이한테 보여? 그럼 선생님은 그림이 보일까? 그래. $\bigcirc \bigcirc$ 이가 하나씩 그림을 설명하면 선생 님이 이 2가지 그림 중 어떤 것인지 맞힐 거야. 선생님이 맞추 면 스티커를 줄 테니까 그 그림 위에 붙여쥐.” 라고 설명한 뒤 충분한 이해를 위해 검사자가 설명하는 역할을 실시해본 후 본 과제를 시행하였다. 검사자는 아동에게 "선생님이 문제를 내볼게. $\bigcirc \bigcirc$ 이가 맞혀봐. 이건...”이라고 설명하며 목표 어휘 의 크기, 형태, 쓰임 등에 대해 자세히 설명해주었다. 연습문항 을 거쳐 아동이 충분히 이해한 것으로 판단되면, 검사자는 아 동이 앞에 놓인 목표어휘에 대해 구체적인 설명을 하도록 유 도했다. 아동이 시작하기 어려워하면 “이건...”이라고 말하며 설명하도록 유도하고 설명을 짧게 하거나 머뭇거리는 모습 이 관찰되면 “음, 선생님 잘 모르겠는데, (검사자가 틀린 그림 을 지적하며) 이 그림인가? 힌트 하나만 더 줄래?”라고 말하며 추가적인 설명할 수 있도록 촉진했다. 검사자는 실험과제 이
후 시행할 수용어휘 과제에 영향을 주지 않기 위해, 아동이 설 명한 목표어휘를 맞힐 때에는 목표어휘는 들려주지 않고 “이 거.”라고 말하며 목표그림을 지적하였다. 검사자의 시범 예시 는 아래 Table 3과 같다.

Table 3

Examples from Description Task

\begin{tabular}{ll}
\hline Target word & Example of description \\
\hline Noun (rabbit) & "It's a white, long-eared animal." \\
\hline Verb (wipe) & "This is what you do, when the window gets dirty." \\
\hline Adjective (fat) & "You ate a lot of food and gained weight." \\
\hline
\end{tabular}

아동이 두 과제의 어휘를 모두 이해하고 있는지 확인하기 위해 검사자는 두 과제를 실시한 후 수용어휘 과제를 추가적 으로 실시하였다. 검사자는 아동에게 "OO는 어디에 있어?" 라고 질문한 후 4 개 그림 중 1 개를 선택하도록 했다. 검사자는 첫 번째 시도에서 응답이 없을 경우 10 초 동안 반응을 기다려 주고 그럼에도 반응이 없다면 두 번째까지 기회를 제공해주어 아동이 $100 \%$ 정확하게 반응한 아동의 자료만을 분석에 사용 하였다.

\section{자료분석}

본 연구는 선행연구 Lavelli와 Majorano (2016)가 제시한 기준 에 따라, 아동의 반응을 발화-제스처 산출양상, 제스처 유형, 발화-제스처 의미적 관계 유형으로 나누어 분석하였다.

발화-제스처 산출양상의 하위범주는 발화, 제스처 + 발화, 제스처의 세 가지로 분류하였다. 발화는 아동이 그림을 보고 제스처 없이 오직 발화로만 산출하는 경우이고, 제스처 + 발 화는 아동이 그림을 보고 해당 그림을 설명하는 제스처와 동 시 또는 1-2초 이내에 의미 있게 발화하는 경우이다. 제스처는 발화는 보이지 않고 제스처로 사물의 특성을 나타내는 경우에 해당한다.

제스처 유형의 하위범주는 지시적 제스처, 표상적 제스처, 기타 제스처로 나누었다. 지시적 제스처란 목표물을 가리키거 나 손에 들고 있는 그림을 실험자를 향해 보여주는 행동을 의 미한다. 표상적 제스처는 어떤 사물의 기능이나 형태, 크기를 나타내는 행위와 동작을 수행하는 행위를 뜻한다. 예를 들어 ‘빗' 그림을 보고 아동이 머리를 빗질하듯이 머리 위 아래로 손 을 움직이는 경우가 이에 해당한다. 기타 제스처는 지시적, 표 상적 제스처로 분류될 수 없는 제스처를 뜻한다. 이는 아동이 단어를 기억하려고 시도 할 때 나타나는 제스처로, 손가락을 
머리나 입으로 가져가는 행위를 취하거나 이야기를 하면서 손 을 공중에서 움직이는 행동이 이에 해당한다.

발화-제스처 간 의미적 관계 유형의 하위범주는 정확한 발 화와 정확한 제스처 $(+S,+\mathrm{G})$, 부정확한 발화와 정확한 제스처 $(-S,+G)$, 정확한 발화와 부정확한 제스처 $(+S,-G)$, 부정확한 발 화와 부정확한 제스처(-S, $-\mathrm{G})$ 로 분류하여 분석하였다. $+\mathrm{S},+\mathrm{G}$ 는 구어로 정확하게 전달된 의미적 정보를 정확한 제스처로 강화(reinforcing)하는 경우이다. $-\mathrm{S},+\mathrm{G}$ 는 구어로 전달되지 않 은 의미적 정보를 제스처로 보완(adding)하는 경우를 뜻한다. $+\mathrm{S},-\mathrm{G}$ 는 구어로 정확하게 의미적 정보를 전달하였으나 부정 확한 제스처로 보완하는 경우에 해당하며, $-\mathrm{S},-\mathrm{G}$ 는 구어로 부 정확하게 전달된 의미적 정보를 부정확한 제스처로 강화하는 경우를 의미한다.

이상의 분석 체계에 따라 모든 제스처와 발화는 각 하위범 주별로 빈도수를 계산하였다. 발화-제스처 산출양상은 아동 이 30 개의 목표어휘에 대해서 어떠한 산출양상을 사용하여 명명하거나 설명하는지를 보기 위한 것임으로 아동이 발화와 함께 여러 개의 제스처를 사용하여 표현했더라도 제스처 + 발 화 양상에 1 회만을 부여하였다. 만약 2 초의 쉼 이후 다른 양상 (제스처 혹은 발화)을 사용했다면 이에 대한 빈도수는 추가적 으로 1 회씩 부여하였다. 제스처 유형은 아동이 산출한 모든 제 스처들을 각 하위범주에 해당하는 빈도수를 세어 계산하였다. 발화-제스처 간 의미적 관계 유형은 제스처와 동시에 산출된 발화 사이의 의미론적 관계를 분석하기 위한 것임으로 표상적 제스처 + 발화 양상만을 가지고 각 하위범주에 해당하는 빈도 수를 세어 계산하였다.

아동이 나타낸 제스처는 Stefanini 등(2008)의 기준에 따라 1) 그림의 이름이나 그림을 요구하는 검사자를 향해야 하고 2) 제공되는 그림을 잡고 있거나 빈손에서 수행될 수 있어야 한 다는 기준을 가지고 분석되었다. 또한 제스처는 아동이 자신 의 몸 앞 공간에서 손을 움직일 때를 시작으로 간주하였고, 손 움직임의 궤도나 위치가 변경되거나 또는 손 움직임에 2초 동 안의 쉼이 있는 경우 종료한 것으로 간주했다(예. 아동이 목표 그림을 가리킨 다음 2 초의 쉼 이후 목표그림과 관련된 동작을 취하면 총 2 번의 제스처로 간주). 아동이 산출한 발화도 2 초 동안의 쉼이 있는 경우 종료한 것으로 간주하였다.

\section{평가자간 신뢰도}

제스처-발화 산출 양상, 제스처 유형, 제스처-발화 의미적 관 계 유형의 신뢰도를 확인하기 위해 언어병리학 전공 석사과
정 학생인 제 2 평가자를 채점과정에 참여시켜 평가자 간 신 뢰도(inter-rater reliability)를 산출하였다. 각 집단 별(3명씩)로 $25 \%$ (총 9명)에 해당하는 자료를 무작위로 선정해 위 분석 기 준에 따라 연구자와 제 2 평가자가 독립적으로 분석 후 빈도수 를 기준으로 일치도(agreement)를 구하였다. 그 결과 발화-제 스처 산출양상, 제스처 유형, 발화-제스처 의미적 관계 유형의 일치도는 각각 $98.7 \%, 99.1 \%, 98.2 \%$ 로 나타났다.

\section{자료의 통계적 처리}

본 연구에서는 IBM SPSS Statistics 26.0 (IBM Co., Armonk, $\mathrm{NY})$ 을 사용하여 통계분석을 실시하였다. 첫 번째 연구 질문에 대한 분석의 경우, 과제 및 발화-제스처 산출양상을 피험자 내 요인으로, 집단을 피험자 간 요인으로 설정하여 $2 \times 3 \times 3$ (과 제 $\times$ 발화-제스처 산출양상 $\times$ 집단) 삼원혼합분산분석(threeway mixed ANOVA)을 실시하였다. 두 번째 연구 질문에 대한 분석은 과제 및 제스처 유형을 피험자 내 요인으로, 집단을 피 험자 간 요인으로 설정하여 $2 \times 3 \times 3$ (과제 $\times$ 제스처유형 $\times$ 집 단) 삼원혼합분산분석(three-way mixed ANOVA)을 실시하였 다. 세 번째 연구 질문에 대한 분석은 과제 및 제스처-발화 의 미적 관계 유형을 피험자 내 요인으로, 집단을 피험자 간 요인 으로 설정하여 $2 \times 4 \times 3$ (과제 $\times$ 제스처-발화 의미적 관계 유형 $\times$ 집단) 삼원혼합분산분석(three-way mixed ANOVA)을 실시하 였다. 연구문제 $1,2,3$ 모두 이후의 유의한 차이를 보인 변인 을 살펴보기 위해 피험자 간, 피험자 내 모두 Bonferroni 사후 검정을 실시하였다.

\section{Results}

\section{집단 간 과제 및 발화-제스처 산출양상에 따른 빈도의 차이}

세 집단 간 과제 및 발화-제스처 산출양상에 따른 출현빈도가 통계적으로 유의미한지 알아보기 위해 집단(3) $\times$ 과제 $(2) \times$ 발 화-제스처 산출 양상(3)에 따른 출현빈도에 대한 삼원혼합분 산분석을 실시한 결과를 Table 4와 Table 5에 제시하였다.

분석 결과, 발화-제스처 산출양상에 대한 주효과가 통계적 으로 유의하였다 $\left(F_{(2,60)}=214.267, p<.001\right)$. 즉 취학 전 아동들 은 그림을 보고 이름대기와 설명하기를 할 때 '발화’로만 표현 하는 양상이 가장 높은 것으로 나타났다. 발화-제스처 산출양 
Table 4

Descriptive Statistics for Modality of Expression

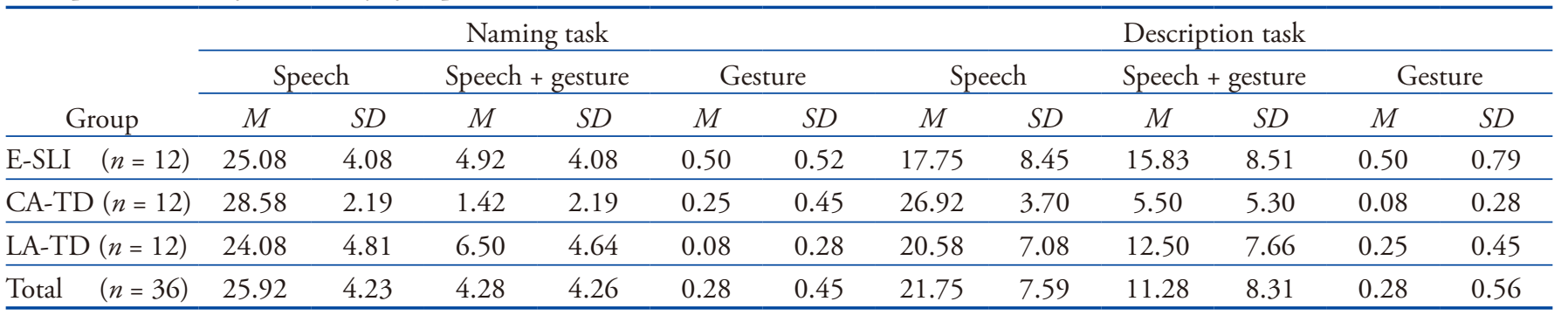

Note. E-SLI = children with expressive specific language impairment; CA-TD = typically developing children matched for chronological age; LA-TD = typically developing children matched for language age.

Table 5

Statistical Results for Modality of Expression

\begin{tabular}{|c|c|c|c|c|c|}
\hline & SS & $d f$ & MS & $F$ & $p$ \\
\hline Group & 0.528 & 2 & 0.264 & 0.848 & .437 \\
\hline Task & 48.167 & 1 & 48.167 & $25.511^{* * *}$ & .000 \\
\hline Modality of expression & 20853.481 & 2 & 10426.741 & $214.267^{* * *}$ & .000 \\
\hline Task $\times$ Group & 1.861 & 2 & 0.931 & 0.493 & .615 \\
\hline Modality of expression $\times$ Group & 1241.463 & 4 & 310.366 & $6.378^{* *}$ & .004 \\
\hline Task $\times$ Modality of expression & 1146.333 & 2 & 573.167 & $43.459^{* * *}$ & .000 \\
\hline Task $\times$ Modality of expression $\times$ Group & 247.889 & 4 & 61.972 & $4.699^{* *}$ & .002 \\
\hline
\end{tabular}

Note. ${ }^{* *} p<.01{ }^{* * *} p<.001$.

상에 유의한 차이가 있는지를 살펴보기 위해 Bonferroni 사후 검정을 실시한 결과, 발화와 발화 + 제스처, 발화와 제스처, 발 화 + 제스처와 제스처 간 통계적으로 모두 유의한 차이를 보 였다. 과제에 대한 주효과도 통계적으로 유의하였다 $\left(F_{(1,33)}=\right.$ $25.511, p<.001)$. 이는 제스처의 사용 빈도는 이름대기 과제에 서 보다 설명하기 과제에서 유의하게 높음을 의미한다. 집단 에 대한 주효과 $\left(F_{(2,33)}=0.848, p>.05\right)$ 는 통계적으로 유의하지 않은 것으로 나타났다.

발화-제스처 산출양상과 집단에 따른 출현빈도 대한 이차상 호작용은 통계적으로 유의하였다 $\left(F_{(4,60)}=6.378, p<.01\right)$. 이에 따 른 LMATRIX와 MMATRIX 명령문을 사용하여 상호작용 대비 효과를 살펴본 결과, 표현언어부진 아동과 생활연령일치 아동 $(p<.01)$ 그리고 언어연령일치 아동과 생활연령일치 아동 $(p<$ .01)간 발화와 발화 + 제스처에서 출현빈도 차이가 제스처에서 출현빈도 차이에 비해 유의하게 큰 것으로 나타났다. 이것은 취 학 전 아동들은 이름대기 과제 설명하기 과제에서 모두 제스처 양상만을 사용하는 경우는 거의 없음을 의미한다. 또한 표현언 어부진 아동과 언어연령일치 아동은 발화와 제스처를 동시에 사용하며 표현하는 발화 + 제스처 양상의 빈도가 생활연령일치 아동에 비해 유의하게 높았다(Figure 1 참조).

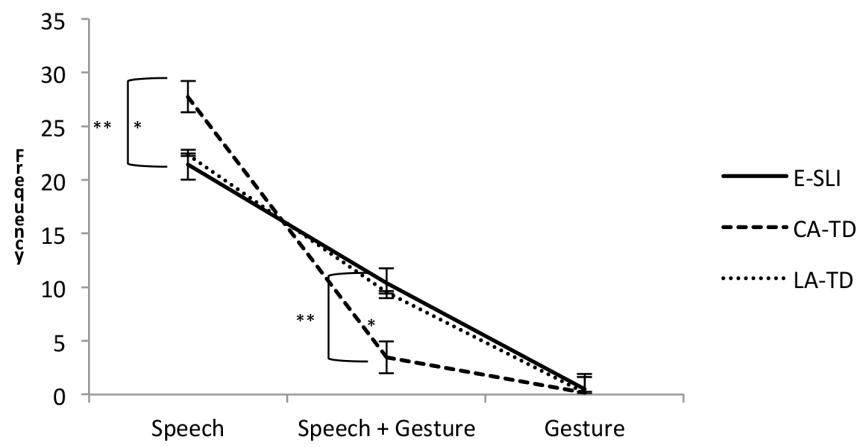

Figure 1. Frequency of modality of expression and group.

또한, 집단과 과제에 따른 출현빈도 대한 이차상호작용은 통계적으로 유의하지 않았으나 $\left(F_{(2,33)}=0.493, p>.05\right)$, 발화제스처 산출양상과 과제에 따른 출현빈도 대한 이차상호작용 이 통계적으로 유의하였다 $\left(F_{(2,66)}=43.459, p<.001\right)$. 이에 따른 MMATRIX 명령문을 사용하여 상호작용 대비효과를 살펴본 결과, 오직 발화에서 과제 간 차이가 제스처에서 과제 간 차이 에 비해 유의하게 컸고 $(p<.001)$, 발화 + 제스처에서 과제 간 차이가 제스처에서 과제 간 차이에 비해 유의하게 컸으며 $(p$ <.001), 발화 + 제스처에서 과제 간 차이가 발화에서 과제 간 차이에 비해 유의하게 큰 것으로 나타났다 $(p<.001)$. 즉 취학 
전 아동들은 이름대기 과제에서 오직 발화로만 표현하는 빈 도가 가장 높았고, 설명하기 과제에서는 발화와 제스처를 동 시에 사용하며 표현하는 발화 + 제스처의 빈도가 가장 높았다 (Figure 2 참조).

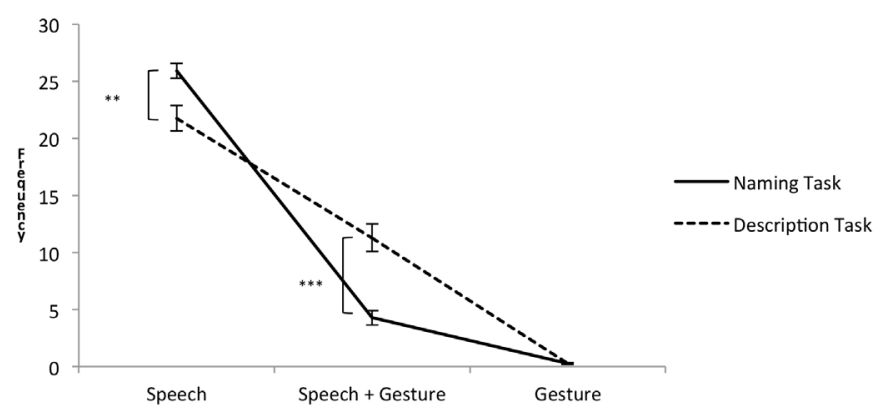

Figure 2. Frequency of modality of expression and task.

집단, 발화-제스처 산출양상, 과제에 따른 출현빈도에 대한 삼차상호작용은 통계적으로 유의하였다 $\left(\mathrm{F}_{(4,66)}=4.699, p<.01\right)$. 이에 대한 사후검정으로 집단 별로 발화-제스처 산출양상 및 과제에 따른 출현빈도 차이를 살펴보기 위해 각 집단별로 이원 반복분산분석(Two-way repeated ANOVA)을 실시하였다. 그 결 과, 생활연령일치 아동은 이름대기 과제와 설명하기 과제에서 모두 오직 발화로만 표현하는 빈도가 높아 과제 간 차이가 크 지 않았다. 그러나 표현언어부진 아동과 언어연령일치 아동은 설명하기 과제에서 오직 발화로만 표현하기 보다는 발화와 제 스처를 동시에 사용하며 표현하는 발화 + 제스처의 빈도가 유 독 높아 과제 간 차이가 큰 것으로 나타났다(Figure 3 참조).

\section{집단 간 과제 및 제스처 유형에 따른 제스처 사용 빈도의 차이}

세 집단 간 과제 및 제스처 유형에 따른 출현빈도가 통계적으
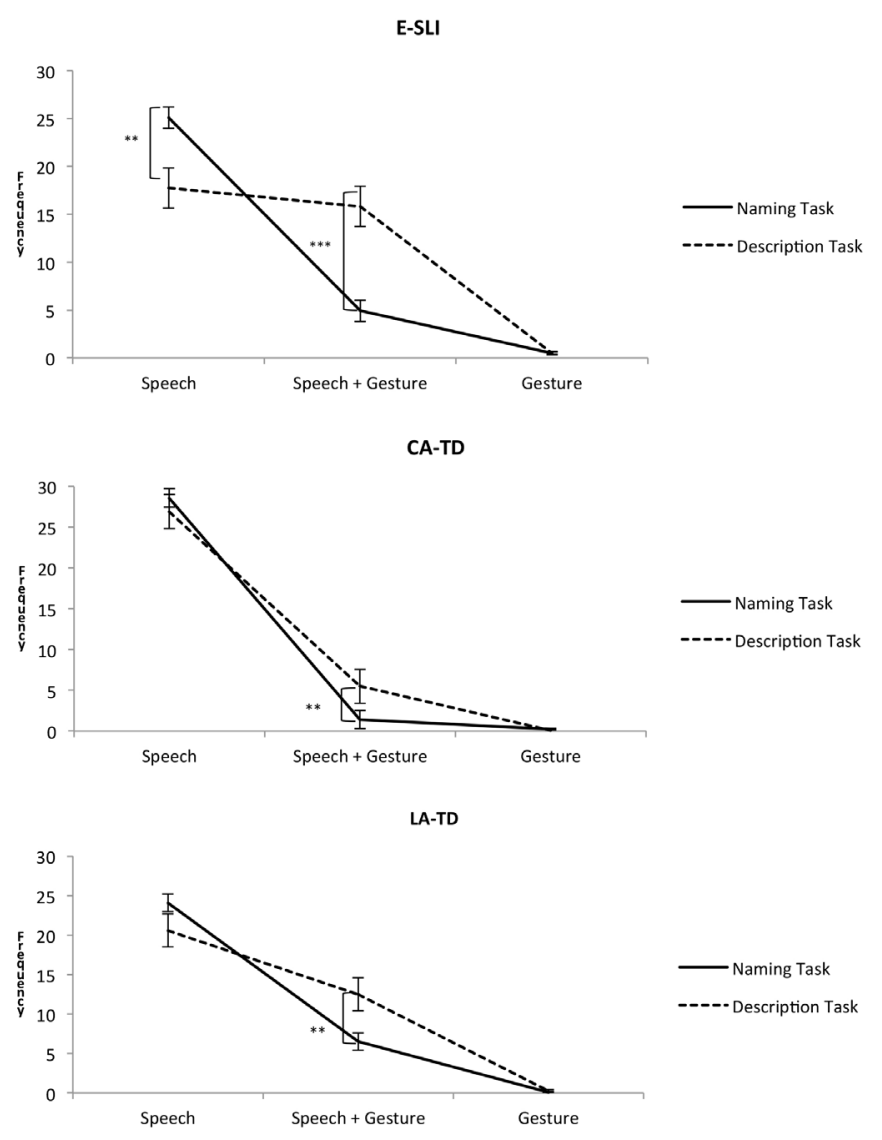

Figure 3. Frequency of modality of expression, task, and group.

로 유의미한지 알아보기 위해 집단(3) $\times$ 과제 $(2) \times$ 제스처 유형 (3)에 따른 출현빈도에 대한 삼원혼합분산분석을 실시한 결과 를 Table 6과 Table 7에 제시하였다.

분석 결과, 집단에 대한 주효과가 통계적으로 유의하였다 $\left(F_{(2,33)}=6.127, p<.01\right)$. 즉 그림을 보고 이름대기와 설명하기 를 할 때 표현언어부진 아동의 제스처 빈도가 가장 높았다. Bonferroni 사후검정을 실시한 결과 표현언어부진 아동과 생 활연령을 일치시킨 아동 간 통계적으로 유의한 차이를 보였으

Table 6

Descriptive Statistics for Types of Gestures

\begin{tabular}{|c|c|c|c|c|c|c|c|c|c|c|c|c|}
\hline \multirow{2}{*}{ Group } & \multicolumn{6}{|c|}{ Naming task } & \multicolumn{6}{|c|}{ Description task } \\
\hline & \multicolumn{2}{|c|}{ Deictic gestures } & \multicolumn{2}{|c|}{$\begin{array}{c}\text { Representational } \\
\text { gestures }\end{array}$} & \multicolumn{2}{|c|}{ Other gestures } & \multicolumn{2}{|c|}{ Deictic gestures } & \multicolumn{2}{|c|}{$\begin{array}{c}\text { Representational } \\
\text { gestures }\end{array}$} & \multicolumn{2}{|c|}{ Other gestures } \\
\hline E-SLI $\quad(n=12)$ & 2.75 & 2.38 & 2.83 & 3.43 & 0.25 & 0.62 & 14.42 & 14.71 & 11.00 & 10.64 & 0.50 & 1.00 \\
\hline $\mathrm{CA}-\mathrm{TD}(n=12)$ & 0.58 & 1.44 & 1.42 & 2.78 & 0.00 & 0.00 & 1.42 & 2.61 & 5.17 & 5.18 & 0.25 & 0.62 \\
\hline
\end{tabular}


Table 7

Statistical Results for Types of Gestures

\begin{tabular}{lccccc}
\hline \multirow{2}{*}{ Group } & $S S$ & $d f$ & $M S$ & $F$ & $p$ \\
\cline { 2 - 6 } & 541.898 & 2 & 270.949 & $6.127^{* *}$ & .005 \\
\hline Task & 820.560 & 1 & 820.560 & $44.878^{* * *}$ & .000 \\
\hline Types of gestures & 1235.704 & 2 & 617.852 & $16.481^{* * *}$ & .000 \\
\hline Task $\times$ Group & 239.565 & 2 & 119.782 & $6.551^{* *}$ & .004 \\
\hline Types of gestures $\times$ Group & 383.102 & 4 & 95.775 & $2.555^{*}$ & .047 \\
\hline Task $\times$ Types of gestures & 374.037 & 2 & 187.019 & $6.445^{* *}$ & .003 \\
\hline Task $\times$ Types of gestures $\times$ Group & 370.083 & 4 & 56.470 & 1.946 & .113 \\
\hline
\end{tabular}

Note. ${ }^{* *} p<.01 .{ }^{* * *} p<.001$

나 표현언어부진 아동과 언어연령일 일치시킨 아동, 생활연령 을 일치시킨 아동과 언어연령을 일치시킨 아동 간 유의한 차 이는 나타나지 않았다. 또한 과제에 대한 주효과가 통계적으 로 유의하였다 $\left(F_{(1,33)}=44.878, p<.001\right)$. 즉 이름대기 과제보다 설명하기 과제일 때 제스처를 유의하게 높게 사용했다.

제스처 유형에 대한 주효과는 통계적으로 유의하였다 $\left(F_{(2,60)}\right.$ $=16.481, p$ <.001). 즉 제스처의 빈도는 표상적 제스처, 지시적 제스처, 기타 제스처 순으로 표상적 제스처의 빈도가 가장 높 았다. Bonferroni 사후검정을 실시한 결과 지시적 제스처와 표 상적 제스처 간 유의한 차이를 보이지 않았으나 기타 제스처 와 지시적 제스처, 기타 제스처와 표상적 제스처 간 유의한 차 이를 나타냈다.

집단과 제스처 유형에 따른 출현빈도에 대한 이차상호작용 또한 통계적으로 유의하게 나타났다 $\left(F_{(4,66)}=2.555, p<.05\right)$. 이 에 따른 LMATRIX와 MMATRIX 명령문을 사용하여 상호작 용 대비효과를 살펴본 결과, 표현언어부진 아동은 생활연령일 치 아동에 비해 지시적 제스처를 유의하게 높게 사용하여 나 타난 결과로 분석되었다 $(p<.01)$. 표현언어부진 아동과 언어 연령일치 아동의 제스처 유형에 따른 출현빈도 간 차이는 나 타나지 않았다(Figure 4 참조).

집단과 과제에 따른 제스처 출현빈도에 대한 이차상호작용 이 통계적으로 유의하였다 $\left(F_{(2,33)}=6.551, p<.001\right)$. 이에 대한 상호작용을 검증하기 위해서 0ne-way ANOVA를 실시한 결과, 생활연령일치 아동 $(p<.05)$ 의 과제 간 차이는 표현언어부진 아동 $(p<.01)$ 과 언어연령일치 아동 $(p<.01)$ 의 과제 간 차이에 비해서 작은 것으로 나타났다. 즉 유의한 이차상호작용은 표 현언어부진 아동과 언어연령일치 아동이 그림을 보고 설명을 할 때 유독 제스처의 사용을 높게 한 것으로 해석된다(Figure 5 참조).

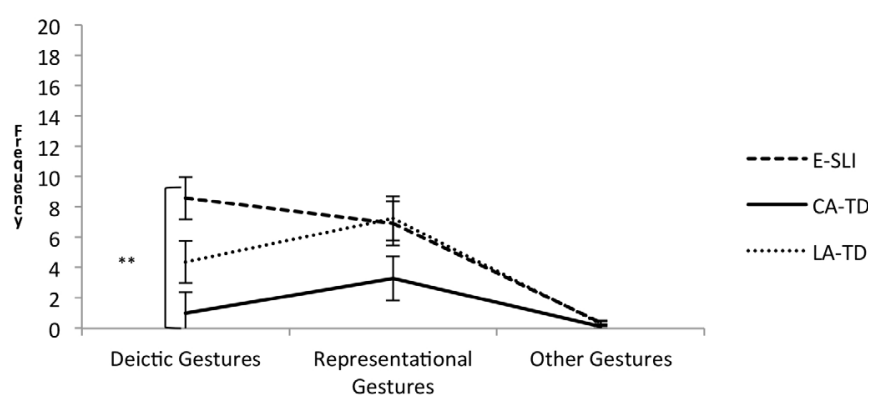

Figure 4. Frequency of types of gesture and group.

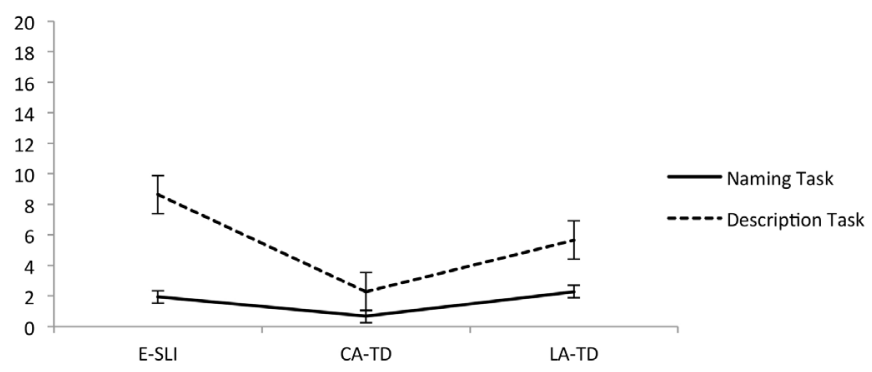

Figure 5. Frequency of task and group.

제스처 유형과 과제에 따른 제스처 출현빈도에 대한 이차상 호작용이 통계적으로 유의하였다 $\left(F_{(2,60)}=6.445, p<.001\right)$. 이에 MMATRIX 명령문을 사용하여 상호작용 대비효과를 살펴본 결과, 지시적 제스처 $(p<.001)$ 와 표상적 제스처 $(p<.001)$ 의 과 제 간 차이가 기타 제스처에 비에 유의하게 컸으며, 지시적 제스 처의 과제 간 차이가 표상적 제스처의 과제 간 차이에 비해 유 의하게 작은 것으로 나타났다 $(p<.01$, Figure 6 참조). 집단, 과 제, 제스처 유형에 따른 제스처 출현빈도에 대한 삼차상호작용 이 통계적으로 유의하지 않았다 $\left(F_{(4,60)}=1.679, p>.05\right)$. 


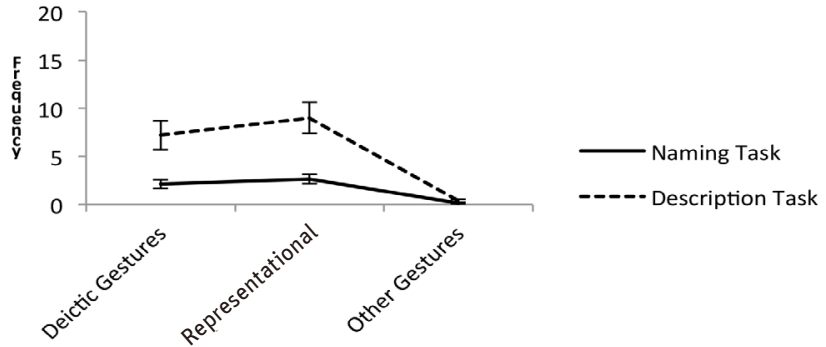

Figure 6. Frequency of types of gesture and task.

\section{집단 간 발화-제스처 의미적 관계 유형 및 과제에 따른 표상적 제스처 사용 빈도 차이}

세 집단 간 과제 및 발화-제스처 의미적 관계 유형에 따른 출현 빈도가 통계적으로 유의미한지 알아보기 위해 집단(3) $\times$ 과제 (2) $\times$ 발화-제스처 의미적 관계 유형(4)에 따른 출현빈도에 대한 삼원혼합분산분석을 실시한 결과는 Table 8과 Table 9와 같다.

분석 결과, 집단에 대한 주효과가 통계적으로 유의하지 않 았다 $\left(F_{(2,33)}=1.306, p>.05\right)$. 즉 표현언어부진 아동과 이와 생 활연령, 언어연령을 일치시킨 일반아동 집단 간 과제 및 의미 적 관계 유형에 따른 출현빈도에 유의한 차이가 없었음을 알 수 있다.

Table 8

Descriptive Statistics for Semantic Relationship Between Gestures and Speech

\begin{tabular}{|c|c|c|c|c|c|c|c|c|c|c|c|c|c|c|c|c|}
\hline \multirow[b]{3}{*}{ Group } & \multicolumn{8}{|c|}{ Naming task } & \multicolumn{8}{|c|}{ Description task } \\
\hline & \multicolumn{2}{|c|}{$+\mathrm{S},+\mathrm{G}$} & \multicolumn{2}{|c|}{$-S,+G$} & \multicolumn{2}{|c|}{$+S,-G$} & \multicolumn{2}{|c|}{$-S,-G$} & \multicolumn{2}{|c|}{$+\mathrm{S},+\mathrm{G}$} & \multicolumn{2}{|c|}{$-S,+\mathrm{G}$} & \multicolumn{2}{|c|}{$+S,-G$} & \multicolumn{2}{|c|}{$-S,-G$} \\
\hline & $M$ & $S D$ & $M$ & $S D$ & $M$ & $S D$ & $M$ & $S D$ & $M$ & $S D$ & $M$ & $S D$ & $M$ & $S D$ & $M$ & $S D$ \\
\hline CA-TD $(n=12)$ & 1.25 & 2.22 & 0.17 & 0.58 & 0 & 0 & 0 & 0 & 4.83 & 4.99 & 0.33 & 0.65 & 0 & 0 & 0 & 0 \\
\hline LA-TD $(n=12)$ & 2.75 & 2.53 & 0.33 & 0.65 & 0 & 0 & 0 & 0 & 8.67 & 12.15 & 0.58 & 0.90 & 0.17 & 0.39 & 0 & 0 \\
\hline
\end{tabular}

Note. +S, +G: correct speech + incorrect gesture; -S, +G: incorrect speech + correct gesture; +S, -G: correct speech + incorrect gesture; -S, $-\mathrm{G}$ : incorrect speech + incorrect gesture.

Table 9

Statistical Results for Semantic Relationship Between Gestures and Speech

\begin{tabular}{|c|c|c|c|c|c|}
\hline & SS & $d f$ & $M S$ & $F$ & $p$ \\
\hline Group & 50.021 & 2 & 25.010 & 1.306 & .285 \\
\hline Task & 180.500 & 1 & 180.500 & $17.848^{* * *}$ & .000 \\
\hline Semantic relation & 1147.958 & 3 & 382.653 & $25.310^{* * *}$ & .000 \\
\hline Task $\times$ Group & 20.021 & 2 & 10.010 & .990 & .382 \\
\hline Semantic relation $\times$ Group & 76.062 & 6 & 12.677 & .839 & .543 \\
\hline Task $\times$ Semantic relation & 341.583 & 3 & 113.861 & $14.801^{* * *}$ & .000 \\
\hline Task $\times$ Semantic relation $\times$ Group & 18.562 & 6 & 3.094 & .402 & .876 \\
\hline
\end{tabular}

과제에 대한 주효과가 통계적으로 유의하였다 $\left(F_{(1,33)}=\right.$ $17.848, p<.001)$. 즉 표상적 제스처와 발화를 동시에 사용하며 표현하는 빈도가 설명하기 과제일 때 가장 높았다.

발화-제스처 의미적 관계 유형에 대한 주효과는 통계적으 로 유의하였다 $\left(F_{(3,99)}=25.310, p<.001\right)$. 즉 취학 전 아동들은 발화를 정확하게 산출함과 동시에 표상적 제스처도 정확하 게 산출한 ${ }^{\prime}+\mathrm{S},+\mathrm{G}$ '를 가장 많이 사용했다. 어느 의미적 관계 유 형에서 유의한 차이가 있는지를 살펴보기 위해 사후검정인 Bonferroni를 실시해본 결과 $+S,+G$ 와 $-S,+G$ 간, $+S,+G$ 와 $+S$, $-\mathrm{G}$ 간, $+\mathrm{S},+\mathrm{G}$ 와 $-\mathrm{S},-\mathrm{G}$ 간, $-\mathrm{S},+\mathrm{G}$ 와 $+\mathrm{S},-\mathrm{G}$ 간, $-\mathrm{S},+\mathrm{G}$ 와 $-\mathrm{S},-\mathrm{G}$ 간 유의한 차이를 나타냈다.

과제와 의미적 관계 유형에 따른 출현빈도에 대한 이차상호 작용이 통계적으로 유의하였다 $\left(F_{(3,99)}=14.801, p<.001\right)$. 이에 따른 MMATRIX 명령문을 사용하여 상호작용 대비효과를 살 펴본 결과, 취학 전 아동들은 정확한 발화와 동시에 정확한 표 상적 제스처를 산출하는 $+S,+\mathrm{G}$ 양상을 설명하기 과제에서 가 장 높게 사용하여 $(p<.001)$ 다른 의미적 관계 양상의 과제 간 차이에 비해 유의하게 큰 것으로 나타났다(Figure 7 참조). 


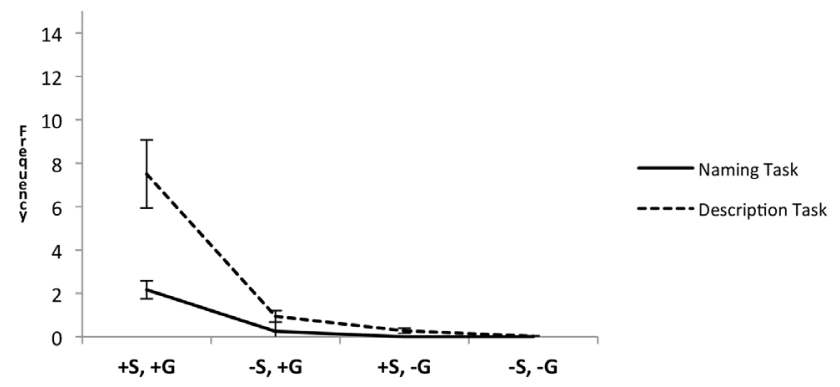

Figure 7. Frequency of semantic relationship and task.

$+S$, +G: correct speech + incorrect gesture; $-S,+$ G: incorrect speech + correct gesture; $+S$, -G: correct speech + incorrect gesture; $-S$, -G: incorrect speech + incorrect gesture.

집단과 의미적 관계 유형에 따른 출현빈도 $\left(F_{(4,66)}=2.402\right.$, $p>.05)$, 집단과 과제에 따른 출현빈도에 대한 이차상호작용 은 통계적으로 유의하지 않았으며 $\left(F_{(4,66)}=2.402, p>.05\right)$, 집 단, 과제, 의미적 관계 유형에 따른 출현빈도에 대한 삼차상호 작용도 통계적으로 유의하지 않았다 $\left(F_{(4,60)}=1.679, p>.05\right)$.

\section{Discussion}

본 연구는 취학 전 표현 언어에서만 지연을 보이는 표현언어 부진 아동과 그들과 언어연령을 일치시킨 일반아동 그리고 생 활연령을 일치시킨 일반아동 집단을 대상으로 이름대기 및 설 명하기 과제를 통해 제스처-발화 산출 양상, 제스처 유형, 제 스처-발화 의미적 관계 유형에 대해 비교분석해 구체적인 특 성을 파악하고자 하였다. 연구 문제에 따른 연구 결과를 정리 하면 다음과 같다.

첫 번째 연구 질문은 세 집단 간 발화-제스처의 산출양상 및 과제에 따른 출현빈도에 유의한 차이가 있는지 살펴보는 것이었다. 연구 결과, 발화-제스처 산출양상에 대한 주효과는 유의한 것으로 나타났다. 즉 취학 전 아동들은 그림을 보고 명 명하거나 설명할 때 오직 발화로만 표현한 빈도가 가장 높았 고 다음으로 발화와 제스처를 함께 조합하며 표현한 빈도가 높게 나타났다. 오직 제스처로만 표현하는 반응은 가장 적게 보였다. Hong과 $\operatorname{Kim}$ (2001)은 20개월 이후부터 아동들은 제 스처만 사용하여 의사소통 의도를 전달하기 보다 발화 또는 발화 + 제스처의 형태로 의사소통 의도를 산출한다고 하였다. 본 연구에서도 3-5세인 대상 아동들은 오직 제스처로만 표현 하기 보다는 발화 또는 발화 + 제스처의 양상으로 표현하는 경 우가 많다는 것을 알 수 있었다.

또한 집단과 발화-제스처 산출양상의 이차상호작용이 유 의하여 집단 간 발화-제스처 산출양상 따른 출현빈도에 차이
를 보였다. 집단 간 차이가 컸던 발화와 발화 + 제스처 양상에 서 집단 간에 통계적으로 유의한 차이가 있는지 알아보기 위 해 0ne-way ANOVA를 실시한 결과, 표현언어부진 아동과 언 어연령일치 아동은 생활연령일치 아동보다 발화와 제스처를 함께 조합하며 표현하는 빈도가 유의하게 더 높았으며, 오직 발화로만 표현하는 빈도는 생활연령이 일치된 아동이 언어연 령일치 아동과 표현언어부진 아동에 비해 높은 것으로 나타닜 다. 전형적인 언어 발달 과정을 살펴보았을 때, 언어발달 초기 단계에는 제스처와 발화 간 밀접한 연관성을 보인다(Capone $\&$ McGregor, 2004). 그리고 아동들이 말을 시작한 이후에 오 직 발화로만 표현하는 것보다는 발화와 제스처를 함께 조합 하여 표현할 때 더 많은 의미적 정보를 전달하며(Iverson \& Goldin-Meadow, 2005), 발화와 제스처를 함께 조합하여 표현 할 때 복잡한 언어적 구조를 증가시키기 위한 기반을 만들 수 있는 것이다(Özçalişkan \& Goldin-Meadow, 2005). 따라서 표현 언어부진 아동들도 자신의 제한된 표현언어능력을 발달해나 가는 과정에서 발화와 제스처를 함께 사용하여 더 많은 의미 적 정보를 전달하려고 했던 것이라 이해할 수 있다.

상호작용 분석 결과, 발화-제스처 산출양상과 과제의 이차 상호작용이 유의하였는데 취학 전 아동들이 이름대기 과제에 서는 오직 '발화’로만 표현하는 빈도가 가장 높았고, 설명하기 과제에서는 발화와 제스처를 조합하며 표현하는 빈도가 가장 높은 것으로 분석되었다. 선행연구에는 이름대기 과제에서 제 스처의 빈도수가 작았기 때문에 제스처와 발화 간 의미적 관 계 유형에 대한 분석이 어려웠다(Lavelli \& Majorano, 2016). 따 라서 본 연구에서는 좀 더 자연스러운 상황에서 인지 및 언어 적 부담을 높일 수 있는 설명하기 과제를 추가하였고, 그 결과 모든 집단의 아동들은 제스처를 발화와 함께 조합하여 높은 빈도로 사용함을 확인하였다. 제스처의 사용은 인지적인 부담 을 감소시켜 구어적 표현을 보다 쉽게 할 수 있도록 도와주는 역할을 한다는 점을 이해한다면(Ingersoll \& Lalonde, 2010), 표 현언어부진 아동들은 설명하기 과제의 높은 개념화 요구 때문 에 자신의 의사소통 능력의 한계에 자주 부딪혔고 이러한 인 지적 부담을 줄이고자 제스처를 발화와 함께 빈번하게 사용했 을 것이라 해석할 수 있다.

삼차상호작용 분석 결과, 발화-제스처 산출양상, 과제, 집 단의 삼차상호작용이 유의하게 나타났다. 즉, 언어연령일치 아동과 표현언어부진 아동의 과제 간 차이가 생활연령일치 아 동의 과제 간 차이에 비해 유독 컸으며, 표현언어부진 아동의 두 과제 간 발화-제스처 산출양상은 언어연령일치 아동과 비 슷한 양상을 보였음을 알 수 있었다. 다시 말해 표현언어부진 
아동과 언어연령일치 아동은 이름대기 과제보다 설명하기 과 제에서 상대적으로 높은 인지 및 언어적 부담을 갖게 되는데, 이로 이해 발화와 제스처를 조합하며 표현하는 발화 + 제스처 양상이 높게 나타난 것으로 유추할 수 있다. 이는 본 연구에서 사용한 설명하기 과제가 이름대기 과제보다 집단 간의 제스처 빈도 차이를 뚜렷하게 보여주었음을 의미한다.

본 연구의 두 번째 연구 질문은 세 집단 간 제스처 유형 및 과제에 따라 제스처 사용 빈도에 유의한 차이가 있는지 살펴 보는 것이었다. 연구결과, 집단에 대한 주효과는 통계적으로 유의하였다. 즉 표현언어부진 아동의 제스처 빈도는 생활연령 을 일치시킨 아동보다 유의하게 높았고, 언어연령을 일치시킨 아동과는 비슷했다. 이러한 결과는 표현언어부진 아동의 발화 + 제스처 양상의 빈도가 생활연령일치 아동보다 높았기 때문 으로 해석된다.

제스처 유형에 대한 주효과와 집단과 제스처 유형의 이차상 호작용은 유의하였다. 즉 취학 전 아동들의 지시적, 표상적 제 스처의 사용빈도는 기타 제스처 사용빈도에 비해 높았으며, 유 의한 이차상호작용은 기타 제스처의 집단 간 차이가 지시적, 표상적 제스처의 집단 간 차이에 비해 유독 작은 것에 기인하 는 것으로 해석된다. 지시적 제스처와 표상적 제스처에서 집단 간 통계적으로 유의한 차이가 있는지 알아보기 위해 0ne-way $\mathrm{ANOVA}$ 를 실시한 결과, 표현언어부진 아동은 생활연령일치 아동보다 지시적 제스처를 발화와 함께 조합하여 유의하게 높 은 빈도로 사용함을 확인하였다. 이는 표현언어부진 아동이 그 림을 손가락으로 지적함으로써 목표단어의 지시대상에 주의 를 집중시키며 목표단어에 대한 의미론적 지식을 이끌어내고 (Capone, 2007), 인식한 명사 또는 서술어를 자신이 들은 표현 과 연관 시키는 것에 도움이 될 수 있다는 연구결과를 바탕으 로 해석할 수 있다(Stefanini, Recchia, \& Caselli, 2008). 즉, 표현 언어부진 아동은 자신의 부족한 표현능력을 보완하기 위해 지 시적 제스처를 높은 빈도로 사용하였다는 점을 알 수 있다.

과제에 대한 주효과와 집단과 과제, 제스처 유형과 과제의 이차 상호작용이 유의하였던 것은 이름대기 과제에서보다 설 명하기 과제에서 지시적, 표상적 제스처 사용빈도가 높았으 며, 명명하기보다는 설명할 때 표현언어부진 아동과 언어연령 일치 아동의 지시적, 표상적 제스처의 빈도가 생활연령일치 아동에 비해 높았기 때문이다. 이는 앞서 설명한바와 같이 모 든 집단에서 발화-제스처 산출 양상 중 발화 + 제스처 양상을 이름대기 과제에서 보다 설명하기 과제에서 더 많이 사용했기 때문으로 해석된다. 다시 말해 설명하기 과제는 높은 개념화 능력을 요구하기 때문에 아동들은 자신의 의사소통 능력의 한
계에 자주 부딪혀, 이에 대한 인지적 부담을 줄이고자 더 높은 빈도로 제스처를 사용하였다고 볼 수 있다.

본 연구의 세 번째 연구문제는 세 집단 간 발화-제스처 의 미적 관계 유형 및 과제에 따라 출현빈도에 유의한 차이가 있 는지 살펴보는 것이었다. 표현언어부진 아동과 일반아동 간 '발화+제스처' 산출이 어떤 차이를 보이는지, 더 심층적인 의 미적인 관계를 알아보기 위해 표상적 제스처와 함께 나타난 발화의 의미 관계 특성들을 분석하였다. 분석 결과, '표상적 제 스처+발화'의 출현빈도는 발화-제스처 의미적 관계 유형에 따 라 유의한 차이를 보였다. 취학 전 아동들은 발화-제스처 의미 적 관계 유형 중 정확한 발화를 정확한 제스처로 강화하는 $+S$, $+\mathrm{G}$ 를 가장 많이 사용하였으며, 다음으로 부정확한 발화를 정 확한 제스처로 보완하는 $-S,+G$ 를 많이 사용하는 것으로 나타 났다. 즉 취학 전 아동들은 발화와 표상적 제스처를 조합하여 사용할 때 정확한 발화와 정확한 표상적 제스처를 사용하여 표현하는 경우가 가장 빈번함을 의미한다.

상호작용 분석 결과, 과제에 대한 주효과와 과제와 의미적 관계 유형의 이차상호작용이 통계적으로 유의하게 나타난 것 은 이름대기 과제에서보다 설명하기 과제에서 표상적 제스처 + 발화의 빈도가 유독 높았으며, 의미적 관계 유형 중 정확한 발 화에 정확한 제스처로 강화하는 유형의 빈도가 이름대기 과제 에서보다 설명하기 과제에서 유의하게 높았기 때문이다. 이는 앞에서 반복적으로 설명하고 있는 표현언어부진 아동과 언어 연령일치 아동의 발화 + 제스처 조합의 출현빈도가 설명하기 과제에서 유독 높았고, 제스처 유형 중 표상적 제스처 사용의 빈도가 설명하기 과제에서 높았던 점을 통해 이해할 수 있다. 즉 설명하기 과제는 높은 개념화 능력을 요구하므로, 자신의 의 사소통 능력 이상의 요구를 받는 아동들은 인지적 부담을 낮추 고자 더 높은 빈도로 제스처를 사용한다고 해석할 수 있다.

이상의 연구 결과를 종합하여보면, 표현언어부진 아동은 자신의 제한된 구어적 표현능력을 지지하고 촉진하기 위해서 발화와 함께 지시적, 표상적 제스처를 사용하며, 더 많은 의미 적 정보를 전달하고자 하는 것으로 해석할 수 있다. 이처럼 높 은 빈도로 사용되는 표현언어부진 아동의 발화와 제스처 조합 은 표현언어능력이 발달해나가는 하나의 과정이라고 볼 수 있 다. 표현언어부진 아동은 오직 발화로만 표현했을 때 성공적 으로 의사소통하지 못하는 경험을 자주 겪는다. 때문에 표현 언어부진 아동은 자신의 말이 상대방에게 적절히 전달될 수 없다는 것을 인식할 가능성이 있으며, 오직 발화로 표현하기 보다는 제스처와 발화를 함께 사용했을 때 의사소통에 성공할 가능성이 높아질 것이라 추측할 수 있다. 
본 연구는 표현언어부진 아동이 사용하는 제스처가 많은 의 미적 정보를 전달하며 상대방과 성공적인 의사소통을 수행하 려는 하나의 수단임을 보여준다. 따라서 이러한 아동들을 교육 하는 교사 및 임상가는 아동의 제스처 사용을 주의 깊게 살펴 보는 것이 필요하다는 점을 시사한다. 그들의 의사소통능력을 평가할 때 구어뿐만 아니라, 제스처와 같은 비구어적인 의사소 통 능력에 대한 평가가 필요할 것이며, 교육과 중재과정에서도 제스처에 담긴 의미를 세심하게 파악하여 소통하고, 아동 스 스로 제스처를 충분히 사용하도록 촉진하여 부족한 구어 소통 능력을 보완하고 지지하도록 지도할 필요가 있을 것이다.

본 연구에 대한 제한점 및 제언은 다음과 같다. 검사자는 과 제를 실시하기 전 아동과 친밀해지기 위해 $5-10$ 분 정도의 시 간을 가졌으나, 낯가림이 심한 소수의 아동의 경우 친밀해지 는 시간이 오래 걸렸고, 검사 과정에서도 지속되어 자연스러 운 제스처 표현을 수집하기가 어려웠다. 따라서 후속연구에서 는 주 양육자처럼 좀 더 익숙한 대화 상대와 함께 할 수 있는 과제가 필요할 것으로 사료된다. 또한 본 연구의 대상자 수가 적고 집단 간 성비를 일치시키지 못하였으므로 본 연구결과를 일반화시키기에는 한계가 있으므로 후속 연구에서는 대상자 의 수의 증가와 성비 통제가 필요하겠다.

\section{Acknowledgements}

This work was supported by the Ministry of Education of the Republic of Korea and the National Research Foundation of Korea (NRF-2018S1A3A2075274).

\section{Notes}

This paper was summarized from the master's thesis of the first author (2019).

\section{Conflict of Interest}

No potential conflict of interest relevant to this article was reported.

\section{References}

\section{In English}

Bello, A., Capirci, O., \& Volterra, V. (2004). Lexical production in children with williams syndrome: Spontaneous use of gesture in a naming task. Neuropsychologia, 42, 201-213. doi:10.1016/S0028-3932(03)00172-6

Blake, J., Myszczyszyn, D., Jokel, A., \& Bebiroglu, N. (2008). Gestures accompanying speech in specifically languageimpaired children and their timing with speech. First Language, 28(2), 237-253. doi:10.1177/0142723707087583

Butcher, C., \& Goldin-Meadow, S. (2000). Gesture and the transition from one-to two-word speech: When hand and mouth come together. In McNeill, D. (Ed.), Language and gesture. (pp. 235257). Cambridge, GB: Cambridge University Press.

Capirci, O., Iverson, J. M., Pizzuto, E., \& Volterra, V. (1996). Gestures and words during the transition to two-word speech. Journal of Child Language, 23(3), 645-673. doi:10.1017/ S0305000900008989

Capone, N. C., \& McGregor, K. K. (2004). Gesture development: A review for clinical and research practices. Journal of Speech, Language, and Hearing Research, 47(1), 173-186. doi:10.1044/1092-4388(2004/015)

Capone, N. C. (2007). Tapping toddlers' evolving semantic representation via gesture. Journal of Speech, Language, and Hearing Research, 50(3), 732-745. doi:10.1044/10924388(2007/051)

Gershkoff-Stowe, L., \& Smith, L. B. (1997). A curvilinear trend in naming errors as a function of early vocabulary growth. Cognitive Psychology, 34(1), 37-71. doi:10.1006/cogp.1997.0664

Ingersoll, B., \& Lalonde, K. (2010). The impact of object and gesture imitation training on language use in children with autism spectrum disorder. Journal of Speech, Language, and Hearing Research, 53(4), 1040-1051. doi:10.1044/10924388(2009/09-0043)

Iverson, J. M., \& Goldin-Meadow, S. (2005). Gesture paves the way for language development. Psychological science, 16(5), 367-371. doi:10.1111/j.0956-7976.2005.01542.x

Johnson, D. J., \& Myklebust, H. R. (1967). Learning disabilities; Educational principles and practices. New York: Grune \& Stratton.

Lahey, M., \& Edwards, J. (1996). Why do children with specific language impairment name pictures more slowly than their peers? Journal of Speech, Language, and Hearing Research, 39(5), 1081-1098. doi:10.1044/jshr.3905.1081

Lahey, M., \& Edwards, J. (1999). Naming errors of children with specific language impairment. Journal of Speech, Language, and Hearing Research, 42(1), 195-205. doi:10.1044/ jslhr.4201.195

Lavelli, M., Barachetti, C., \& Florit, E. (2015). Gestures and speech during shared book reading with preschoolers with specific language impairment. Journal of Child Language, 
42(6), 1191-1218. doi:10.1017/S0305000914000762

Lavelli, M., \& Majorano, M. (2016). Spontaneous gesture production and lexical abilities in children with specific language impairment in a naming task. Journal of Speech, Language, and Hearing Research, 59(4), 784-796. doi:10.1044/2016_ JSLHR-L-14-0356

Leonard, L. B. (2014). Children with specific language impairment (2nd ed.). Cambridge, MA: The MIT Press.

Majorano, M., \& Lavelli, M. (2014). Maternal input to children with specific language impairment during shared book reading: is mothers' language in tune with their children's production? International Journal of Language \& Communication Disorders, 49(2), 204-214. doi:10.1111/1460-6984.12062

Mainela-Arnold, E., Alibali, M. W., Hostetter, A. B., \& Evans, J. L. (2014). Gesture-speech integration in children with specific language impairment. International Journal of Language \& Communication Disorders, 49(6), 761-770. doi:10.1111/14606984.12115

Özçalişkan, S., \& Goldin-Meadow, S. (2005). Gesture is at the cutting edge of language development. Cognition, 96(3), B101-B113. doi:10.1016/j.cognition.2005.01.001

Stefanini, S., Bello, A., Caselli, M. C., Iverson, J. M., \& Volterra, V. (2009). Co-speech gestures in a naming task: Developmental data. Language and Cognitive Processes, 24(2), 168-189. doi:10.1080/01690960802187755

Stefanini, S., Caselli, M. C., \& Volterra, V. (2007). Spoken and gestural production in a naming task by young children with down syndrome. Brain and Language, 101(3), 208221. doi:10.1016/j.bandl.2007.01.005

Stefanini, S., Recchia, M., \& Caselli, M. C. (2008). The relationship between spontaneous gesture production and spoken lexical ability in children with Down Syndrome in a naming task. Gesture, 8(2), 197-218. doi:10.1075/gest.8.2.05ste

Weismer, S. E., \& Hesketh, L. J. (1993). The influence of prosodic and gestural cues on novel word acquisition by children with specific language impairment. Journal of Speech, Language, and Hearing Research, 36(5), 1013-1025. doi:10.1044/ jshr.3605.1013

\section{In Korean}

An, S.-J., Bang, H.-J., \& Lee, S.-H. (2010). The change in the ratio of gesture utilization in 2-3 years old children-Focusing on iconic gestures-. The Korean Journal of Developmental Psychology, 23(1), 33-50.

Hong, G. H., \& Kim, Y.-T. (2001). A longitudinal study of the acquisition of communicative intentions. Communication Sciences \& Disorders, 6(1), 1-21.

Kang, N. R. (2009). Comparing the intervention of sign language and graphic communication board for preschool children with severe down syndrome (Master's thesis). Retrieved from http://riss.kr/link?id=T11551562

Kim, M., \& Son, C. N. (2006). Effects of AAC interventions using device and gesture on the communicative behavior of the students with severe mental retardation. The Journal of Special Education: Theory and Practice, 7(1), 159-176.

Kim, Y., Sung, T., \& Lee, Y. (2003). Preschool Receptive-Expressive Language Scale (PRES). Seoul: Seoul Community Rehabilitation Center.

Mun, S. (2014). Kaufman Assessment Battery for Korean Children (2nd ed.). Seoul: Hakjisa Publisher.

Pae, S., \& Kwak, K. (2011). MacArthur-Bates Communicative Development Inventory-Korean: Words and Gestures. Seoul: Mind Press.

Park, H. (2013). Comparison on iconic gesture comprehension and production characteristics of 3-5 years old children with typical development and children with mild intellectual disabilities (Doctoral dissertation). Retrieved from http://www.riss.kr/ link?id=T13250820

Park, H. J., \& Kim, Y. T. (2018). Characteristics of the iconic gesture comprehension and production in 3- to 5-yearold children with typical development. Journal of SpeechLanguage \& Hearing Disorders, 27(3), 107-122.

\section{ORCID}

Sujin Choi http://orcid.org/0000-000X-7189-4871

Sang-Im Jung http://orcid.org/0000-0003-1389-0404

Young Tae Kim http://orcid.org/0000-0003-1738-6862

Received April 30, 2020

Revision received June 20, 2020

Accepted July 27, 2020 